\title{
PENGEMBANGAN DIVERSIFIKASI OLAHAN BUAH DI DESA BONTO BANGUN KABUPATEN BULUKUMBA MENUJU KAMPUNG AGRO INDUSTRI
}

\author{
Irma Sribianti ${ }^{1}$, Sri Satriani ${ }^{2)}$ Muh. Arief Muhsin ${ }^{3)}$ \\ ${ }^{1}$ Fakultas Pertanian, Universitas Muhammadiyah Makassar \\ email: is sibianti89@yahoo.com \\ ${ }^{2}$ Fakultas Keguruan dan Ilmu Pendidikan, Universitas Muhammadiyah Makassar \\ email: : $\underline{\text { srisatriani@ rocketmail.com }}$ \\ ${ }^{3}$ Fakultas Keguruan dan Ilmu Pendidikan, Universitas Muhammadiyah Makassar \\ email: : arief.m@unismuh.ac.id
}

\begin{abstract}
Bonto Bangun is one of the villages in the district Bulukumba South Sulawesi, which is a plateau region in districts of Rilau Ale which is known as one of the villages that is capable of producing fruits such as durian, rambutan, olive, mangosteen, bananas and the other. Seeing this village has a productivity of fruits are increasing each year so it is possible to develop a diversification of processed fruit. This program of its service to the community, the implementation uses a maximum of 3 months, the program is not a program that only last for three months but forever so that the community's economy can continue to promote the productivity and the government provides wide access to the community night administer such a program is to make it as Owned village by involving farmer groups in collaboration with the PKK village will be divided into several sections according to processing methods so that every farmer groups producing different so it is possible there will be more further processed products diversification otherfruit that can bemade. This activity is expected to be able to become an agro industry village in Bulukumba district.
\end{abstract}

Keywords: diversification, processed fruits, agro industry. 
ISSN

e-ISSN

\section{PENDAHULUAN}

Desa Bonto Bangun merupakan salah satu desa yang berada di kabupaten Bulukumba Sulawesi Selatan yang merupakan wilayah dataran tinggi yang ada di wilayah kecamatan Rilau Ale. Desa ini dikenal sebagai salah satu desa yang mampu memproduksi buah-buahan yang jumlahnya setiap tahun makin bertambah. Banyak jenis buah-buahan tropis yang dihasilkan di desa ini diantaranya: durian, rambutan, langsat, manggis, pisang dan lain-lain.

Pada saat musim panen tiba antara bulan MaretApril adalah waktu puncak panen buah-buahan di desa ini. Walaupun banyak para pedagang yang ingin menyuplai buah-buahan dari desa ini akan tetapi pedagang lebih sering mengeluh tak mampu menanggung suplai buah-buahan yang melimpah sehingga tidak semua buah-buahan dapat dibeli oleh pedagang. Jika buah-buahan tersebut tidak mampu ditampung oleh pedagang karena sangat banyak, maka mereka hanya membiarkan buah-buahan tersebut membusuk di kebun tanpa penanganan lebih lanjut. Selain itu karena terlalu banyaknya buah saat panen menyebabkan daya beli masyarakat sangat rendah karena rata-rata memiliki buah-buahan itu di kebun. Hal ini yang menjadi masalah yang desa ini tiap tahunnya.

Pada dasarnya sebenarnnya masyarakat sedikitdemi sedikit telah mengolah buah-buahan ini menjadi bahan makanan lain sepertibuah durian yang mulai diolah menjadi selai durian dan itupun tidak dipasarkan hanya menjadi konsumsi rumah tangga saja. Padahal semua bagian dari buah durian sendiri dapat didiversifikasi menjadi produk lain yang lebih bernilai jual mulai dari dagingnya hingga bijinya yang bagi masyarakat di desa Bontobangun sebagian kecil dari biji durian hanya dijadikan sebagai bibit, tapi jauh lebih banyak yang dibuang begitu saja karena tidak tahu cara mengolahnya dan mereka pun kurang memiliki pengetahuan tentang kandungan gizi pada biji durian. Padahal menurut penelitian kandungan giji pada biji durian cukup tinggi. Selain itu pisang yang juga merupakan hasil kebun terbesar masyarakat setempat hanya dijual dalam bentuk buahnya saja atau hanya dikonsumsi, padahal setiap bagian dari buah pisang dapat dijadikan produk yang bernilai jual, misalnya kulit pisang. Selama ini masyarakat hanya membuangnya karena mereka tidak memiliki pengetahuan bahwa kulit pisang juga memiliki kandungan gizi yang tidak kalah dengan buah pisang itu sendiri.

. Proses diversifikasi olahan buah tersebut dapat dijadikan sebagai centra pendapatan masyarakat desa teruatama bagi petani. Kedepannya masyarakat dapat mengembangkan sebuah produk olahan yang inovatif dan dapat berdaya saing dengan adanya beberapa pendekatan dari berbagai pihak dalam menunjang kebutuhan masyarakat dari segi pemahaman dalam mengolah sebuah produk yang berkualitas. Pengolahan sebuah produk harus banyak yang terlibat diantaranya pihak akademisi, pemerintah dan pihak industri yang biasa disebut sebagai Triple Helix guna memperhatikan kebutuhan dari sebuah desa yang mempunyai potensi dari segi pemberdayaaan hasil alam dari desa tersebut.

Hasil dari sebuah program pengabdian dapat dilihat dari beberapa luaran yang dihasilkan oleh masyarakat sasaran. Begitupun dengan program yang telah dilaksanakan di desa Bonto Bangun Kecamatan Rilau Ale Kabupaten Bulukumba. Program tersebut tidak adalah suatu bentuk pengabdian kepada masyarakat dengan memberikan sebuah pelatihan tentang pengembangan olahan buah. Gambaran umum masyarakat sebelum adanya program dapat dilihat pada beberapa keadaan yang telah tergambar dari beberapa pelaporan sebelumnya yakni masyarakat belum mampu membuat suatu olahan yang dapat bernilai ekonomis. Bentuk pelatihan dari program ini adalah pengembangan olahan buah yang terdapat pada desa Bonto Bangun, sehingga masyarakat dapat menggali serta memanfaatkan potensi pangan dari daerah tersebut. Dapat dicontohkan dari olahan buah durian, rambutan, pisang, dan buah-buahan yang terdapat didesa Bonto Bangun.

Berdasarkan observasi awal selama ini belum ada pelatihan pengembangan olahan buah yang dapat lebih membantu masyarakat dalam mengolah bahan mereka menjadi suatu produk makanan yang lain. Diversifikasi produk atau pengembangan produk adalah salah satu cara untuk meningkatkan pendapatan masyarakat pengolah melalui berbagai macam cara pengolahan dengan mengubah bentuk fisik bahan menjadi bentuk spesifik/berbeda sehingga menjadi nilai tambah. Melihat desa ini mempunyai produktifitas buah-buahan yang makin meningkat tiap tahunnya sehingga sangat 
memungkinkan untuk mengembangkan deversifikasi olahan buah yang diharapkan desa ini mampu menjadi kampung agro industri yang ada di kabupaten Bulukumba. Dengan potensi yang ada ini direkomendasikanlah sebuah program pengabdian masyarakat "Pengembangan Diversifikasi Olahan Buah di Desa Bonto Bangun Kabupaten Bulukumba Menuju Kampung Agro Industri”.

\section{METODE PELAKSANAAN}

A. Persiapan dan Pembekalan

1. Mekanisme Pelaksanaan

a. Pengurusan Adminstrasi objek program

Kelengkapan

b. Workshop pembekalan diversifikasi olahahan buah kepada mahasiswa

c. Pembagian kelompok mahasiswa yang menjadi pendamping

d. Pembelian alat dan bahan

e. Pembuatan produk olahan dari mahasiswa

f. Evaluasi hasil olahan

g. Pemberian penguatan dengan mengacu pada hasil evaluasi

2. Materi yang diberikan kepada mahasiswa a. Manajemen Kerja (Pengorganisasian)

b. Pemaparan kandungan produk olahan

c. Pelatihan Diversifikasi buah-buahan menjadi produk, dengan diversifikasi olahan berupa sari buah rambutan, kerupuk biji durian, dodol kupis durian, cookies kulit pisang, kerupuk kulit pisang, nugget kulit pisang, dan tepung biji durian.

d. Pengemasan produk

e. Pemasaran

B. Pelaksanaan

Bentuk pelaksanaan dari program ini dapat dilihat dengan menggunakan tiga pendekatan yaitu:

\section{Pre Activity}

Pengenalan dan pemaparan tujuan program dengan malakukan pendekatan dan sosialisasi kepada masyarakat. Bentuk pemaparan program dilakukan dengan melakukan komunikasi secara lansung kepada masyarakat dari rumah ke rumah. Selian itu, pemaparan program dengan melakukan komunikasi ke pihak pemerintah kecamatan, desa, serta setiap kepala dusun dalam mendukung tahap sosialisasi menyeluruh kepada masyarakat. Bentuk sosialisasi ini dilakukan beberapa hari dalam jangka waktu selama 1 minggu.

2. Whilst Activity

Pembinaan masyarakat melalui pelatihan secara lansung di aula kantor desa Bonto Bangun yang diadakan oleh mahasiswa serta demo secara langsung dihadapan masyarakat sehingga masyarakat dapat melihat secara langsung proses pengolahan buah yang telah dideversifikasi menjadi sebuah produk yang berkualitas. Bentuk pelatihan yang telah dilakukan mahasiswa dengan 3 kali tahapan pelatihan selama beberapa minggu dengan rentang waktu yang tidak terlalu jauh. Bentuk pelatihan awal yaitu mengundang seluruh khalayak masyarakat untuk meyaksikan secara lansung pengolahan serta melibatkan masyarakat dalam proses diversifikasi olahan buah. Setelah itu, masyarakat diminta secara lansung mempraktekkan pengolahan buah pisang yaitu cookis kulit pisang, nugget kulit pisang, dan kerupuk kulit pisang serta mahasiswa memperlihatkan beberapa resep olahan buah serta memberikan buku resep kepada masyarakat.

Pada pelatihan kedua, mahasiswa melakukan pelatihan bersama masyarakat terkhusus kepada kelompok ibu PKK dan Kelompok Tani yang ada di desa Bonto Bangun dengan membuat sebuah olahan dari kulit pisang serta masyarakat melakukan olahan secara mandiri dan di damping oleh mahasiswa. Setelah itu, masyarakat merasakan lansung hasil olehan yang telah dibuat yang kemudian diberikan label dan dikemas sedemikian rupa untuk menambah nilai jual dari produk yang telah dibuat.

Pada pelatihan ketiga, masyarakat malakukan sebuah produk olahan yaitu dodol kulit pisang kombinasi rasa durian serta pembuatan nugget kulit pisang yang kemudian masyarakat sendiri melakukannya secara pribadi. Pada tahap ini bahan-bahan pembuatan produk tersebut disediakan sendiri oleh masyarakat guna untuk menyesuaikan serta melihat sejauh mana output dari program ini yang telah disesuaikan dengan luaran yang telah diharapkan penulis. Rentang waktu antara ketiga pelatihan ini sekitaran 1 minggu karena mahasiswa harus melihat hasil olahan masyarakat dirumah serta memberikan 
evaluasi kepada produk yang telah dibuat, sebagaimana workshop yang telah dilakukan kepada mahasiswa sebelum melakukan pekatihan kepada masyarakat.

\section{Post Activity}

Pembinaan yang telah dilakukan sebelumnya akan di evaluasi oleh mahasiswa, serta akan dilakukan pembinaan lanjutan sebelum mengakhiri program yaitu kelompok ibu PKK dan Kelompok Tani dibagi beberapa kelompok untuk menanggapi program pelatihan yang telah dilakukan mahasiswa. Kemudian mahasiswa melakukan komunikasi secara lansung kepada pihak pemerintah setempat tentang kemajuan program yang telah dilakukan oleh mahasiswa. Hal ini dilakukan agar masyarakat dan pemerintah bukan hanya paham akan yang telah dilatihkan akan tetapi mereka dapat meningkatkan kreativitasnya dalam mebuat sebuah produk olahan yang kreatif, produktif, dan kompetitif.

\section{HASIL DAN PEMBAHASAN}

Program pengabdian masyrakat yang telah dirancang sedemikian rupa telah dilaksanakan sesuai dengan yang telah ditargetkan baik dari segi waktu maupun metode pelaksanaannya. Hal ini dapat dilihat dari beberapa hasilnya yang meliputi adanya produk yang telah dikeluarkan oleh mahasiswa KKN-PPM dan hasil olahan produk dari masyarakat sasaran, terbentuknya kelompok masyarakat yang melanjutkan program ini, perencanaan tindak lanjut program sebagai Badan Usaha Milik Desa yang dikelola oleh pemerintah desa Bonto Bangun, dan bertambahnya pengetahuan masyarakat dalam mengembangkan sebuah produk olahan buah yang produktif dan kompetitif sesuai dengan tujuan program. Masyarakat juga lebih kreatif dalam melakukan sebuah pengemasan serta mampu untuk merancang sebuah konsep pemasaran yang dapat mengembangkan usaha dengan mengedepankan kualitas produk.

Dalam realisasi, masyarakat adalah sasaran utama rencana dan realisasi kegiatan $\mathrm{KKN}$ PPM dapat dilihat pada tabel di bawah ini:
Tabel 3.1 Luaran (Output)

\begin{tabular}{|c|c|c|}
\hline Uraian & Rencana/Target & Realisasi \\
\hline $\begin{array}{l}\text { Memberi } \\
\text { kan bekal } \\
\text { kepada } \\
\text { masyarak } \\
\text { at dalam } \\
\text { mengelol } \\
\text { a sebuah } \\
\text { produk } \\
\text { yang } \\
\text { mengemb } \\
\text { angkan } \\
\text { potensi } \\
\text { daerah } \\
\text { serta } \\
\text { sumber } \\
\text { daya alam } \\
\text { yang } \\
\text { belum } \\
\text { terkelola } \\
\text { oleh } \\
\text { masyarak } \\
\text { at desa. }\end{array}$ & $\begin{array}{l}\text { Target peserta } \\
\text { yang diundang } \\
\text { telah melakukan } \\
\text { hal-hal yang telah } \\
\text { disampaikan } \\
\text { dalam pelatihan } \\
\text { yaitu: } \\
\text { - mengelola } \\
\text { produk rumahan } \\
\text { - mempraktekkan } \\
\text { dan meanfaatkan } \\
\text { memanfang daya } \\
\text { sumber yam yang } \\
\text { alam terdapat pada } \\
\text { desa Bonto } \\
\text { Bangun. }\end{array}$ & $\begin{array}{l}\text { - Semua peserta } \\
\text { pelatihan telah } \\
\text { mengelola } \\
\text { produk pada } \\
\text { pelatihan } \\
\text { - Masyarakat } \\
\text { aktif dalam } \\
\text { mempraktekk } \\
\text { an olahan } \\
\text { buah. } \\
\text { - Mahasiswa } \\
\text { melakukan } \\
\text { pelatihan } \\
\text { sesuai JKEM } \\
\text { yang telah } \\
\text { ditentukan. } \\
\text { - Masyarakat } \\
\text { berhasil } \\
\text { menciptakan } \\
\text { sebuah produk } \\
\text { olahan yang } \\
\text { produktif. }\end{array}$ \\
\hline
\end{tabular}

Tabel 3.2 Hasil (Outcome)

\begin{tabular}{|c|c|c|}
\hline Uraian & Rencana/Target & Realisasi \\
\hline $\begin{array}{l}\text { Menghasil } \\
\text { kan produk } \\
\text { yang } \\
\text { mempunya } \\
\text { i nilai jual } \\
\text { yang tinggi } \\
\text { sesuai } \\
\text { dengan } \\
\text { kebutuhan } \\
\text { masyarakat } \\
\text { serta } \\
\text { masyarakat } \\
\text { dapat } \\
\text { mengemba } \\
\text { ngkan } \\
\text { produk } \\
\text { olahan } \\
\text { buah } \\
\text { lainnya. }\end{array}$ & $\begin{array}{ll}\text { Peserta pelatihan } \\
\text { secara kelompok } \\
\text { bisa menghasilkan } \\
\text { produk makanan } \\
\text { yang berasal dari } \\
\text { limbah yang telah } \\
\text { disediakan } \\
\text { mahasiswa dan } \\
\text { peserta } \\
\text { menhasilkan } \\
\text { produk yang } \\
\text { bernilai jual yang } \\
\text { tinggi } \\
\text { berdasarkan yang } \\
\text { arahan } \\
\text { mahasiswa dari } \\
\text { pembimbing }\end{array}$ & 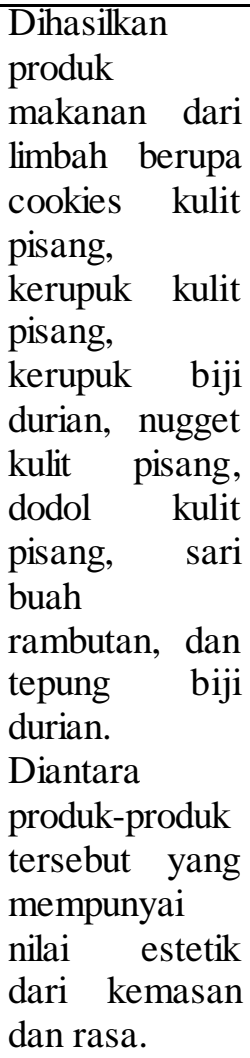 \\
\hline
\end{tabular}


Dalam pelaksanaan program KKN-PPM ini, ada beberapa tahapan yang telah dicapai sebagai bentuk tindak lanjut program kedepan. Adapun kegiatan kegiatan yang telah dilaksanakan adalah sebagai berikut:

a. Melakukan sosialisasi program kerja ke pemerintah setempat dalam rapat koordinasi desa serta sosialisasi ke masyarakat setempat dengan mengunjungi rumah masing-masing warga sekaligus pengenalan. Dalam kegiatan sosialisasi mahasiswa dibagi dalam beberapa kelompok di tiga dusun yang ada di desa Bonto Bangun yakni dusun Bonto Bangun, dusun Buttakeke dan dusun Pa'bentengan. Kegiatan sosialisasi ini dilaksanakan selama satuminggu.

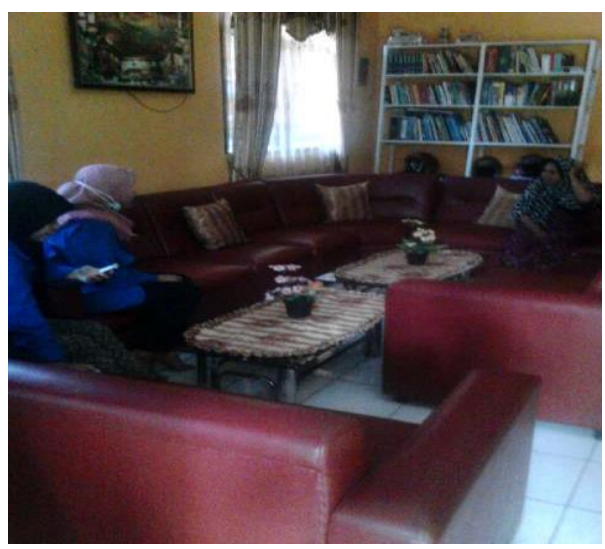

Dok.kegiatan sosialisasi mahasiswa

b. Mahasiswa melakukan uji coba pembuatan sampel produk di posko KKN-PPM. Hal ini bertujuan agar pada saat workshop oleh mahasiswa KKN-PPM tentang pengembangan diversifikasi, masyarakat dapat langsung melihat dan mencoba produk olahan buah hasil diversifikasi mahasiswa KKN-PPM sekaligus sebagai pengenalan produk

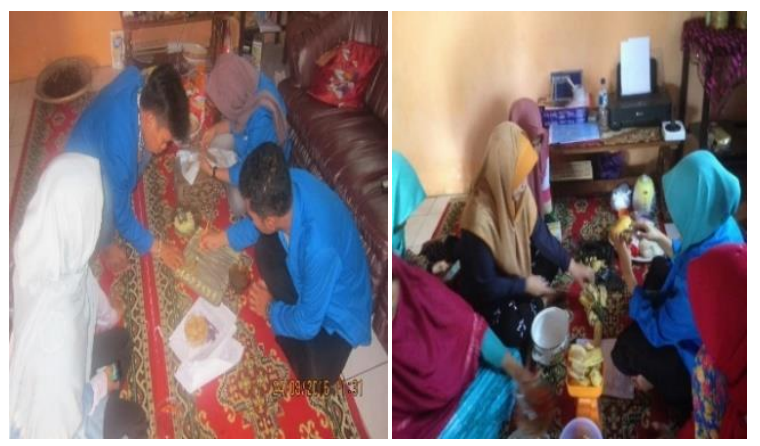

Dok.Uji coba produk oleh mahasiswa c. Mahasiswa melakukan workshop yang merupakan pelatihan tahap pertama yang sedianya diadakan beberapa tahapan pelatihan berikutnya. Pada Pelatihan tahap pertama yang dihadiri masyarakat dan pemerintah desa, diperkenalkan tentang buah-buahan yang merupakan komoditi desa Bontobangun yang dapat didiversifikasi menjadi produk yang bernilai ekonomis serta demonstrasi diversifikasi olahan buah oleh mahasiswa KKN-PPM. Masyarakat diberikan buku panduan resep untuk membantu mereka dalam membuat olahan buah tersebut.
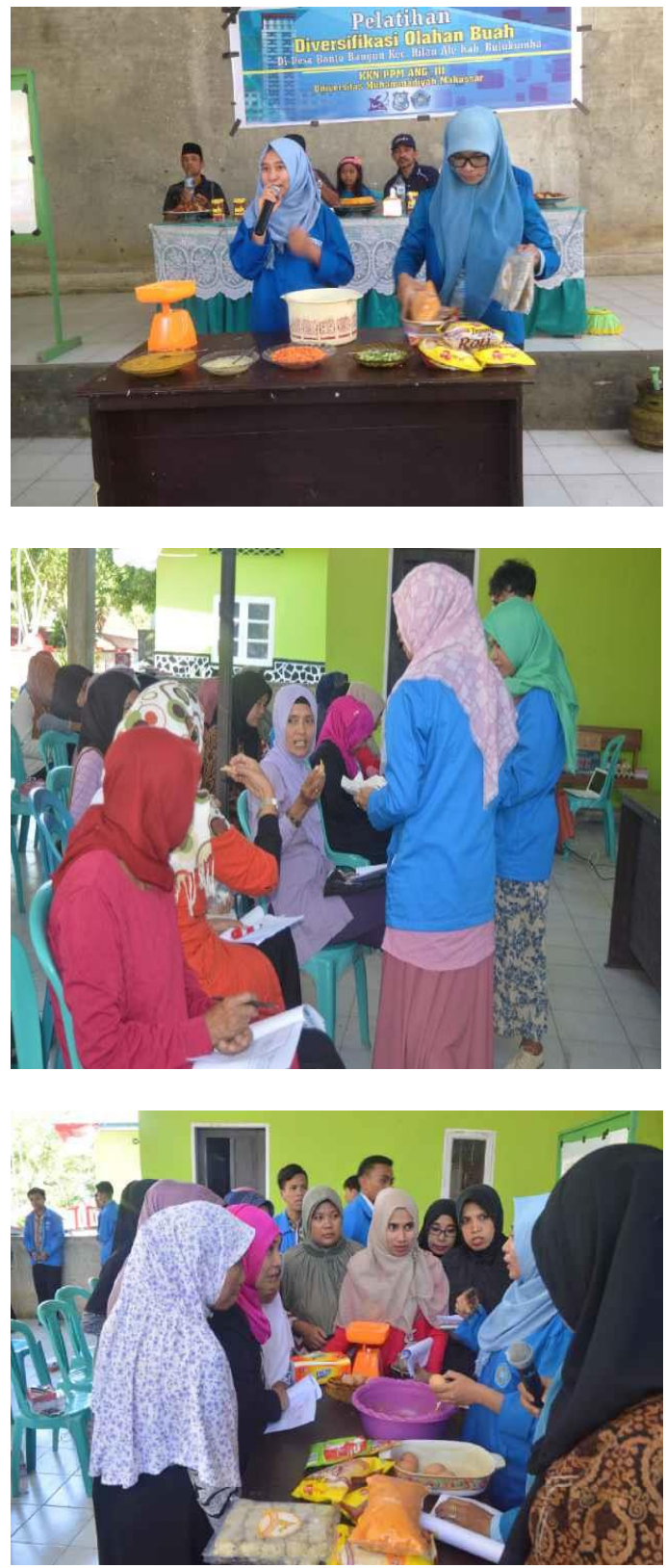

Dokumentasi pelatihan tahap pertama bersama masy arakat setempat 
d. Melakukan koordinasi dengan ibu PKK desa Bonto Bangun dengan Kelompok Tani terkait keberlanjutan pelatihan yakni pelatihan yang melibatkan tim PKK desa Bontobangun sekaligus membentuk kelompok kerja yang dimaksudkan untuk memfokuskan jenis kegiatan pengolahan buah pada setiap kelompok yang akan dijadikan produk dan evaluasi terkait pelatihan sebelumnya. Pada kegiatan koordinasi ini tim penggerak PKK telah membentuk tiga kelompok kerja yang masing-masing kelompok akan bertanggung jawab dalam mengolah dan berinovasi mendiversifikasikan produk yang telah dipraktekkan sebelumnya yakni cookies kulit pisang, tepung biji durian, kerupuk kulit pisang, kerupuk biji durian, nugget kulit pisang dan dodol kulit pisang. Diversifikasi olahan Produk ini tentunya akan bertambah jika suplay buahbuahan durian, rambutan dan langsat akan ada pada saat musim panen tiba.
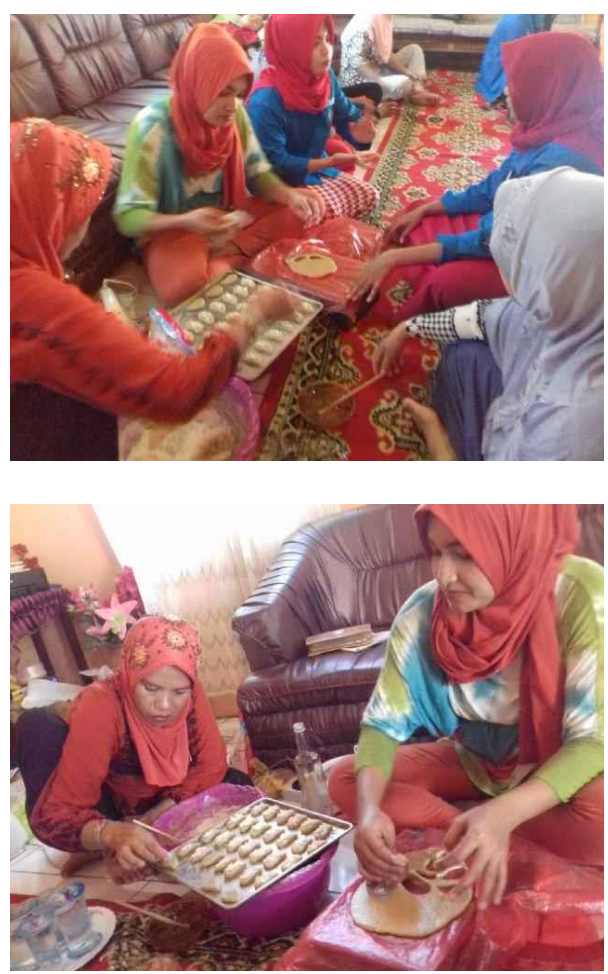

Dok.pelatihan pembuatan cookis kulit pisang dengan tim PKK
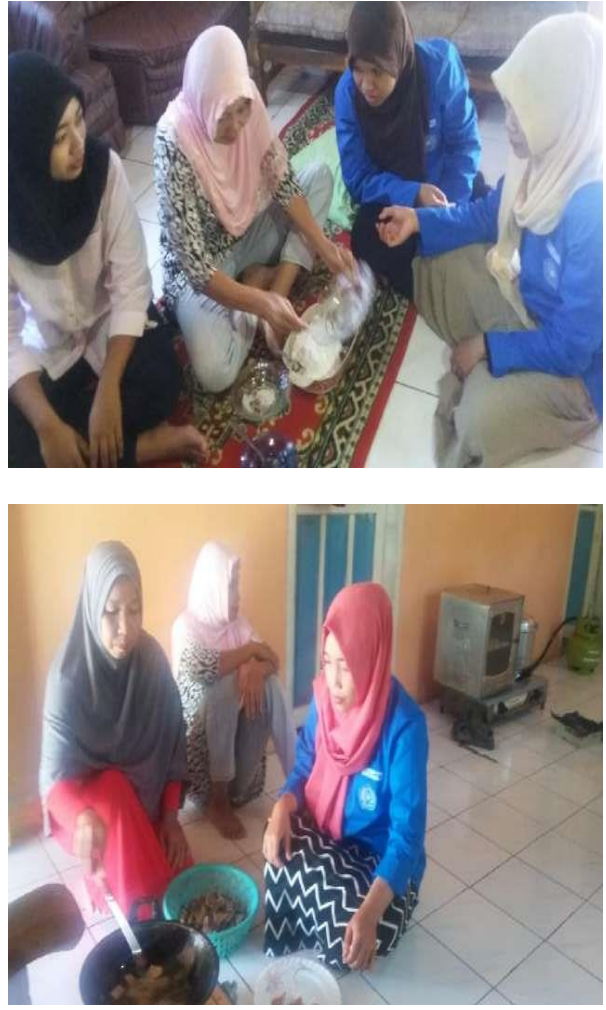

Dok pelatihan pembuatan keripik Kulit pisang dan keripik biji durian bersama Tim PKK
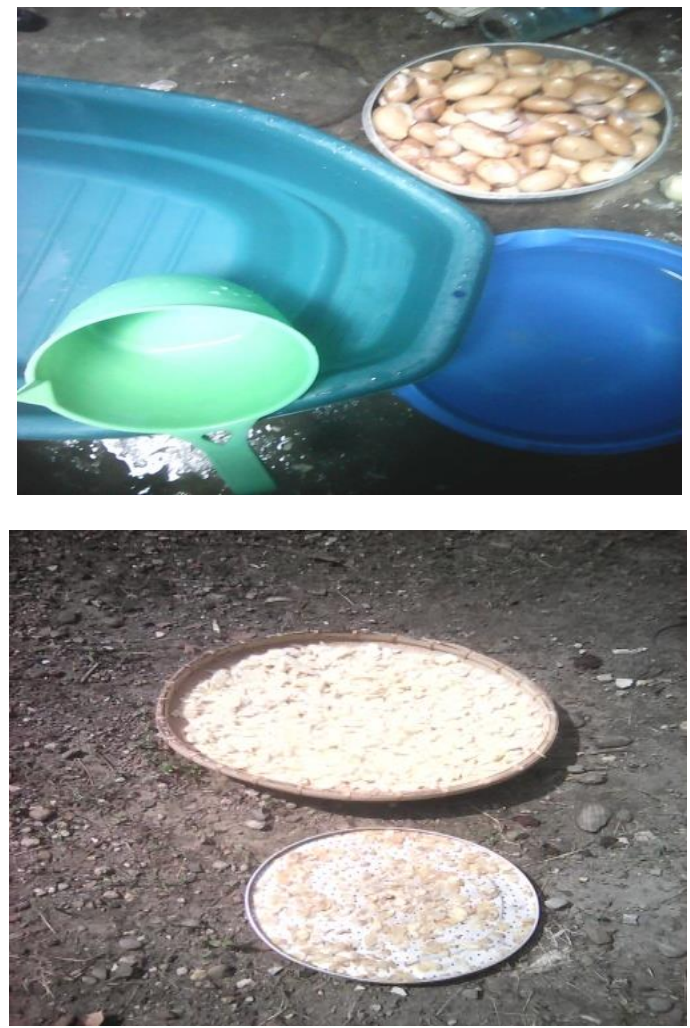

Dok pembuatan Tepung Biji Durian 


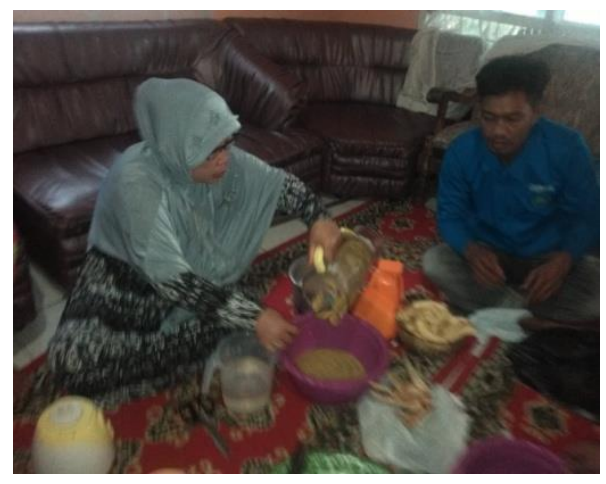

Dok.Pembuatan Nugget Kulit Pisang

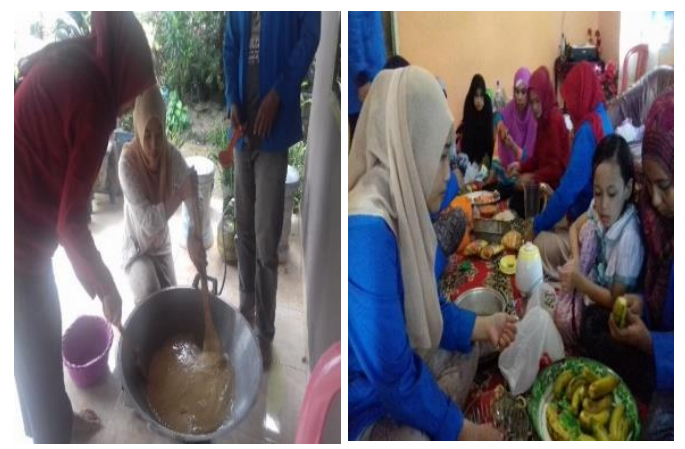

Dok.Pembuatan Dodol Kulit Pisang

e. Mahasiswa melakukan refleksi terkait pelatihan yang kemudian hasil pelatihan berupa produk dikemas sedemikian rupa. Kemudian diperlihatkan kepada pemerintah setempat untuk melihat kelayakan dari produk sebagai Badan Usaha Milik Desa.

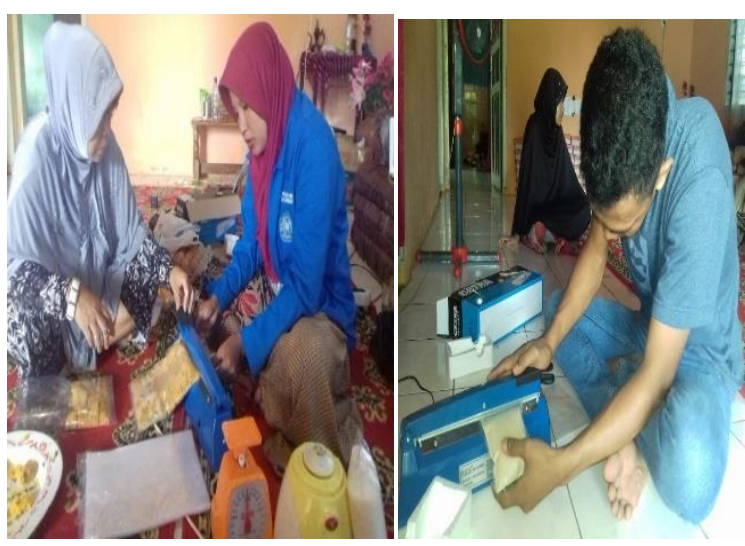

Dok.Pengemasan Produk
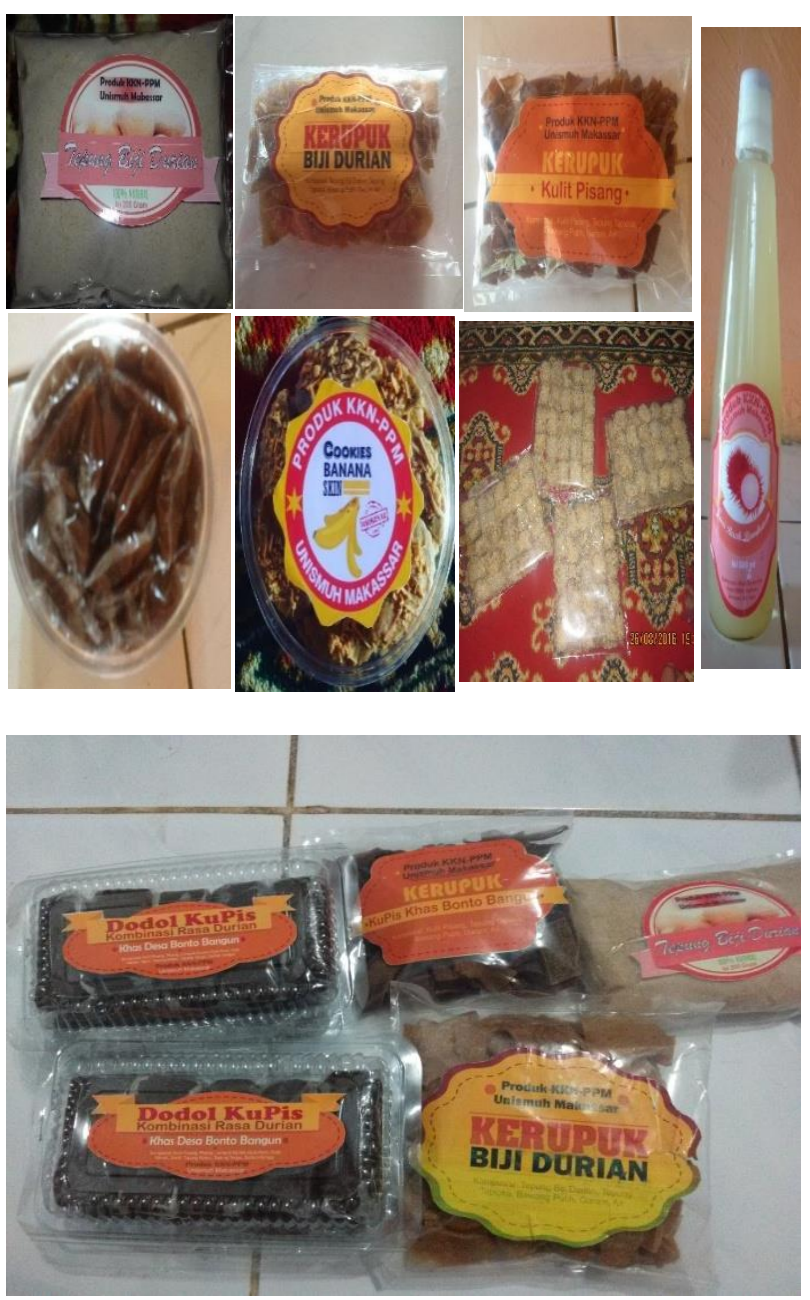

Dok.Produk KKN_PPM dan Tim PKK desa Bontobangun

f. Pembentukan tim penanggung jawab yang akan mengelola secara lanjut ketika program ini telah selesai sesuai dengan target waktu yang telah ditentukan.

\section{KESIMPULAN}

Pelaksanaan program semacam ini merupakan suatu sumbangsih perguruan tinggi dalam mewujudkan Tri Dharma Perguruan Tinggi yaitu pengabdian masyarakat. Dengan beberepa pertimbangan yang telah dilakukan oleh pelaksana terkait pelaksanaan program yang dilaksanakan di pedesaan harus membuat sebuah keyakinan akan kemampuan pelaksana untuk melaksanakan program tersebut. Adapun hal-hal yang tidak sesuai dengan perencanaan adalah sebuah kesalahan yang muntlak untuk diperbaiki kedepannya. Hal-hal yang menjadi proses diatas telah menghasilkan beberapa luaran diantaranya terciptanya masyarakat yang 
mampu mengembangkan sebuah produk olahan yang bernilai ekonomis dan kompetitif dari segi rasa dan kemasan, terbentuknya pemahaman masyarakat dalam mengolah sumber daya alam yang dapat dikembangkan menjadi produk hasil olahan desa, terciptanya sumber daya manusia yang menyeluruh, menjadikan masyarakat desa sebagai titik awal dalam pengembangan bangsa, dan terciptanya kembali peran mahasiswa sebagai agen penggerak bangsa.

\section{REFERENSI}

Fitri. 2013. Diversifikasi Olahan Pangan. Bukit Asam: Jogjakarta.

Marsigit, Wuri. 2010. Pengembangan Diversifikasi Produk Pangan Olahan Lokal Bengkulu Untuk Menunjang Ketahanan Pangan Berkelanjutan, Badan Agribisnis Bengkulu, Bengkulu

Situmorang, Ricky. 2009. Analisis Usaha Keripik Biji Durian. Sumatra Utara 